\title{
Галина Олександрівна ПУДИЧЕВА
}

кандидат економічних наук, викладач кафедри економіки підприємства, Одеський національний економічний університет, e-mail: pudycheva@mail.ru

\section{ЕНЕРГЕТИЧНА БЕЗПЕКА ПІДПРИСМСТВ В КОНТЕКСТІ СТАЛОГО РОЗВИТКУ ЕКОНОМІКИ}

Пудичева, Г. О. Енергетична безпека підприємств в контексті сталого розвитку економіки / Галина Олександрівна Пудичева // Вісник сочіально-економічних досліджень: зб. наук. прачь; за ред. М. I. Звєрякова (голов. ред.) та ін. (ISSN 2313-4569). - Одеса: Одеський начіональний економічний університет. - 2016. Bun. 1. - № 60. - C. 179-185.

\begin{abstract}
Анотація. У статті розглянуто концепцію сталого розвитку в історичному аспекті. Досліджено зв'язок енергетичної безпеки зі сталим розвитком економіки. Проаналізовано структуру спожсиання енергї в Україні та світі за видами палива та напрямками споживання. Уточнено визначення енергетичної безпеки підприсмства. Запропоновано заходи з підвищення енергетичної безпеки підприємств за основними напрямками підвищення енергетичної ефективності та використанням альтернативних (відновлювальних) джерел енергії. Виділено низку специфічних питань, які потребують вирішення.
\end{abstract}

Ключові слова: енергетична безпека; сталий розвиток; альтернативні джерела енергї; енергоефективність; паливно-енергетичні ресурси.

\section{Галина Александровна ПУДЫЧЕВА}

кандидат экономических наук, преподаватель кафедры экономики предприятия, Одесский национальный экономический университет, e-mail: pudycheva@mail.ru

\section{ЭНЕРГЕТИЧЕСКАЯ БЕЗОПАСНОСТЬ ПРЕДПРИЯТИЙ В КОНТЕКСТЕ УСТОЙЧИВОГО РАЗВИТИЯ ЭКОНОМИКИ}

Пудычева, Г. А. Энергетическая безопасность предприятий в контексте устойчивого развития экономики / Галина Александровна Пудычева // Вестник сочиально-экономических исследований: сб. науч. трудов; под. ред. М. И. Зверякова (глав. ред.) и др. (ISSN 2313-4569). - Одесса: Одесский национальный экономический университет. - 2016. - Bыn. 1. - № 60. - C. 179-185.

Аннотация. В статье рассмотрена концепџия устойчивого развития в историческом аспекте. Исследована связь энергетической безопасности с устойчивым развитием экономики. Проанализирована структура потребления энергии в Украине и в мире по видам топлива и по направлениям потребления. Уточнено определение энергетической безопасности предприятия. Предложены мероприятия по повышению энергетической безопасности предприятия по основным направлениям повышения энергетической эффективности и использования альтернативных (возобновляемых) источников энергии. Выделен ряд специифических вопросов, которые требуют решения.

Ключевые слова: энергетическая безопасность; устойчивое развитие; альтернативные источники энергии; энергоэффективность; топливно-энергетические ресурсы.

\section{Halyna PUDYCHEVA}

PhD in Economics, Lecturer of Enterprise Economics Department, Odessa National Economics University, e-mail: pudycheva@mail.ru

\section{ENERGY SECURITY OF ENTERPRISES IN THE CONTEXT OF ECONOMY SUSTAINABLE DEVELOPMENT}

Pudycheva, H. (2016), Energy security of enterprises in the context of economy sustainable development. Ed.: M. Zveryakov (ed.-in-ch.) and others [Enerhetychna bezpeka pidpryiemstv v konteksti staloho rozvytku ekonomiky; za red.: M. I. Zveriakova (gol. red.) ta in.], Socio-economic research bulletin; Visnik social'no-ekonomičnih doslidžen' (ISSN 2313-4569), Odessa National Economic University, Odessa, Issue 1, No. 60, pp. 179-185. 
Abstract. The sustainable development concept in the historical aspect is described in the article. The relation of energy security and sustainable development of economy is researched. The structure of energy consumption for types of fuels and directions of consumption in Ukraine and in the world is analyzed. The definition of enterprise energy security is given. The measures of enterprise energy security increase in the main directions of energy efficiency improving and in using alternative (renewable) sources of energy are proposed. A number of specific issues to be solved are identified.

Keywords: energy security; sustainable development; renewables; energy efficiency; fuel.

JEL classification: $0440, Q 010, Q 400$

Постановка проблеми у загальному вигляді. Україна на даний час стикається 3 соціальними, економічними та екологічними викликами, що формують три основні аспекти сталого розвитку. Ці виклики не можуть бути подолані без забезпечення енергетичної безпеки. Розуміючи зв'язок між енергетичною безпекою та сталим розвитком, можна виділити ключові аспекти обох напрямків: використання екологічно чистих, надійних, дешевих джерел енергії у виробничих та невиробничих процесах сприяє економічному зростанню, зниженню негативного впливу на зміну клімату та зростання доброту людини в цілому. Між сталим розвитком та енергетикою існує нероздільний зв'язок. Тому перед суспільством постає завдання щодо розроблення стратегії, яка б поєднувала енергетичну безпеку зі сталим розвитком. Оскільки основними споживачами енергії є підприємства, проблема підвищення їх енергетичної безпеки з метою досягнення сталості є достатньо актуальною.

Аналіз досліджень і публікацій останніх років. Необхідно зазначити, що питанням сталого розвитку присвячено значну кількість наукових праць як зарубіжних, так i вітчизняних учених. Серед них: Г. Дейлі [1], Д. Х. Медоуз, Д. Л. Медоуз, Й. Рендерс, В. В. Беренс [2], що стояли у витоків концепції сталого розвитку; Л. Г. Мельник, O. I. Мельник, I. М. Бурлакова [3], що розглядають сталий розвиток у зв'язку з так званим «озелененням» економіки, яка використовує інновації, що є і прибутковими, і екологічними; Б. М. Данилишин, Л. Б. Шостак [4], які розглядають сталий розвиток як систему відносин суспільного виробництва, за якої досягається оптимальне співвідношення між економічним ростом, нормалізацією якісного стану природного середовища, ростом матеріальних i духовних потреб населення; В. О. Баранник [5], який розглядає енергетичну безпеку як складову сталого розвитку. Однак зазначені науковці застосовують поняття «сталий розвиток» по відношенню до макрорівня, незважаючи на мікрорівень (рівень підприємств).

Виділення невирішених раніше частин загальної проблеми. Зважаючи на те, що підприємства різних галузей є основними споживачами енергії як в Україні, так і в світі, більш детального дослідження потребує взаємозв'язок між енергетичною безпекою підприємств та сталим розвитком економіки. Питання визначення основних індикаторів енергетичної безпеки на підприємствах є недостатньо вивченими. Більш детальної розробки та обгрунтування потребують заходи щодо забезпечення енергетичної безпеки на рівні підприємств з метою досягнення сталого розвитку.

Постановка завдання. Виходячи із зазначеного, метою статті є розкриття основних аспектів сталого розвитку у зв'язку із забезпеченням енергетичної безпеки підприємств, а також визначення основних напрямів розробки заходів 3 підвищення енергетичної безпеки підприємств за умов переходу до сталого розвитку.

Виклад основного матеріалу дослідження. Енергія - це ключовий аспект розвитку сучасного суспільства. Ї̈ використання тісно пов'язано з промисловим виробництвом, транспортом, охороною здоров'я, безпекою харчування, якістю забезпечення водою тощо. Динамічний розвиток цих сфер призводить до зростання обсягів споживання природних ресурсів, зокрема, паливно-енергетичних. Основний виклик для всього світу полягає при цьому в необхідності пошуку засобів для поєднання зростаючого попиту на якісні енергетичні послуги зі зниженням впливу на навколишнє середовище для того, щоб забезпечити реалізацію цілей сталого розвитку. Поняття сталості відображає зв'язок між 
економічним розвитком, якістю навколишнього середовища та соціальною рівністю, тобто сталий розвиток характеризується економічними, екологічними та соціальними аспектами.

Енергетика є одним із найважливіших факторів сталого розвитку. Проблематика 3 цих питань була вперше висвітлена на Конференції ООН з довкілля і розвитку, яка відбулася у 1992 році в Ріо-де-Жанейро. У «Порядку денному на XXI століття» (Agenda 21) особливу увагу було приділено тому факту, що сучасні рівні виробництва та споживання енергії не $\epsilon$ сталими, особливо при збільшенні попиту, та наголошено на важливості використання енергетичних ресурсів таким чином, щоб це відповідало цілям охорони здоров'я людини та навколишнього середовища.

На дев'ятій сесії Комісії зі сталого розвитку (CSD-9), яка відбулася у 2001 році, було погоджено, що найбільша увага має бути приділена розробці, реалізації та впровадженню більш чистих та ефективних енергетичних технологій та наголошено на тому, що необхідні термінові дії з розвитку альтернативних джерел енергії.

Йоганнесбурзький план виконання (JPOI), ухвалений на Світовому Саміті з питань сталого розвитку у 2002 році, також розглядає енергію в контексті сталого розвитку. У відповідь на це в 2004 році було створено механізм OOH-Енергія (UN-Energy) для більш скоординованої та узгодженої програми з боку установ OOH. CSD-14 та CSD-15 у 2006 та 2007 роках були зосереджені на низці питань, що включали зокрема використання енергії в інтересах сталого розвитку.

У 2011 році Генеральним Секретарем ООН було започатковано ініціативу «Стала енергетика для всіх», яка спрямована на досягнення трьох основних цілей до 2030 року: забезпечення загального доступу до сучасних енергетичних послуг, подвоєння швидкості підвищення енергоефективності та подвоєння частки відновлювальних джерел енергії в глобальній енергетиці.

У 2012 році Резолюція Генеральної асамблеї ООН оголосила 2012 рік Міжнародним роком сталої енергетики для всіх, що сприяло успішному виконанню багатьох дій та зобов'язань, які сприяють сталому енергетичному майбутньому. Крім того, за підсумками Конференції зі сталого розвитку 2012 року «Ріо+20» було задекларовано важливу роль, яку відіграє енергія в процесі сталого розвитку.

У 2014 році Резолюцією Генеральної Асамблеї ООН було проголошено 2014-2024 роки Десятиліттям ООН Сталого розвитку для всіх, що вступило в силу задля прискорення виконання цілей досягнення сталого розвитку. Крім того, Генеральна Асамблея $\mathrm{OOH}$ запропонувала низку цілей сталого розвитку, що включає, зокрема, цілі в сфері енергетики. Станом на 2015 рік енергія стоїть у центрі глобальних зусиль 3 переходу до енергетичних систем з низьким вмістом вуглецю, зеленої економіки та до сталого розвитку в кінцевому рахунку [6].

Така увага 3 боку світової спільноти до проблем енергетики викликана іï безпосереднім зв'язком з цілями сталого розвитку. Саме енергія відіграє провідну роль в питаннях економічного розвитку, охорони навколишнього середовища та досягнення Цілей Розвитку Тисячоліття.

3 одного боку, вона спричиняє значний вплив на формування доходів за рахунок економії на витратах або виробництва енергії. 3 іншого боку, прискорення використання енергії може загрожувати здоров'ю людей та підсилювати екологічне навантаження. На світовому рівні постачання, перетворення та використання енергії є одним з найголовніших факторів, що чинить негативний вплив на зміну клімату за рахунок викиду парникових газів. Тому перед суспільством постає дуже важке завдання щодо розроблення стратегії розвитку, яка зможе поєднувати як енергетичну безпеку, так і сталий розвиток.

Стала енергетика передбачає раціональне використання енергетичних ресурсів зі збереженням можливості їх використання майбутніми поколіннями. Тому саме з розвитком концепції сталого розвитку виникає проблема екологізації енергетики.

Енергія пов'язана 3 кожною із трьох складових сталого розвитку (економічною, соціальною, екологічною). 
По-перше, суттєвий вплив на використання енергії справляють ціни на енергоносії. Вони можуть впливати на вибір та поведінку споживача. 3 іншого боку, високі ціни можуть стимулювати підприємства здійснювати дослідження та розвиток додаткових ресурсів, створювати ініціативи для інновацій та підвищення ефективності, а також залучення інвестицій. Розвиток енергетичної системи не може мати місце без інвестицій у іiі обладнання та інфраструктуру.

По-друге, використання енергії пов'язане 3 широким колом соціальних проблем. Надання сучасних, невисокої вартості, енергетичних послуг може задовольнити багато соціальних потреб, що підвищить рівень життя населення та знизить негативний вплив на здоров'я людей.

По-третє, забруднення навколишнього середовища дуже тісно пов'язано 3 виробництвом та споживанням енергії, особливо викопного палива, оскільки саме воно призводить до викидів в атмосферу вуглекислого газу [7, с.11-12].

Таким чином, енергія відіграє дуже важливу роль у забезпеченні сталого розвитку. Крім того, наслідки використання енергії в економіці мають прояв як на локальному рівні, так і на регіональному та глобальному, адже так званий «енергетичний ланцюг» містить безліч процесів, починаючи від видобутку енергетичних ресурсів, їх переробки, транспортування, зберігання та закінчуючи кінцевим споживанням та утилізацією відходів.

Розглянемо структуру споживання енергії в світі. У 2013 році обсяг кінцевого споживання складав 9301,06 млн. т н.е., а саме: вугілля - 1069,41 млн. т н.е. (11,5\%), сирої нафти та нафтопродуктів - 3716,34 млн. т н.е. (39,96\%), природного газу 1400,68 млн. т н.е. (15,06\%), біопалива та відходів - 1130,35 млн. т н.е. $(12,15 \%)$, інші (геотермічна, сонячна, вітрова, теплова енергія тощо) - 1984,28 млн. т н.е. (21,33\%) (рис. 1). При цьому, у галузях промисловості було спожито 2702,44 млн. т н.е. (29,01\% від загальних обсягів споживання), а у сфері транспорту - 2563,52 млн. т н.е. (27,56\% відповідно) [8, с.37].

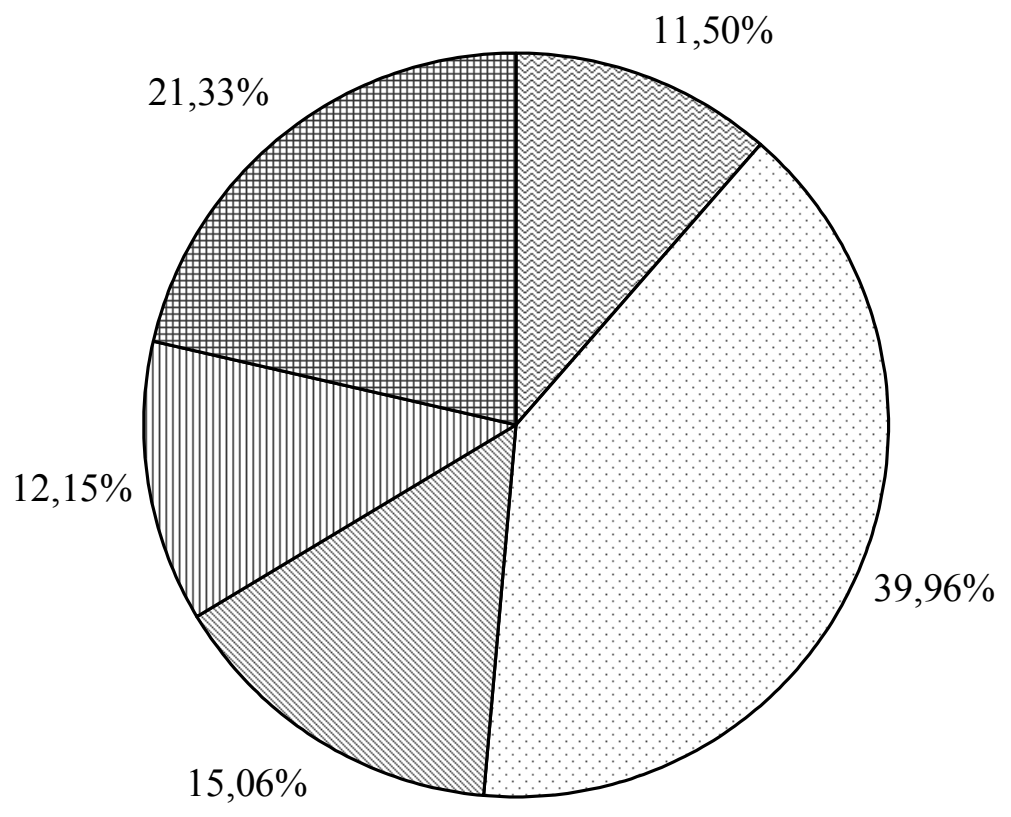

图Вугілля
$\square$ Сира нафта та
нафтопродукти
Природний газ
⿴囗Біопаливо та
відходи
团 Інше

Рис. 1. Структура кінцевого споживання енергії в світі у 2013 р.

Таким чином, економіку світу можна назвати енергозалежною від викопного палива, оскільки найбільша питома вага у кінцевому споживанні припадає саме на викопні (невідновлювальні) види палива, запаси яких є вичерпними та неможливими до відтворення в найближчій перспективі. Оскільки вони $\epsilon$ вичерпними, a також нерівномірно розподіленими між країнами, це ставить під загрозу енергетичну безпеку як окремих регіонів, так і цілих країн. 
Крім того, за даними Міжнародного Енергетичного Агентства загальний обсяг виробництва енергії в світі у 2013 році склав 13594 млн. т н.е., причому викиди вуглекислого газу склали 32190 млн. т, що в розрахунку на одну особу - 4,52 т $\mathrm{CO}_{2}$ [8, с.48-49]. Звісно, це спричиняє значний негативний вплив на сталість світового розвитку.

Ситуація в Україні характеризується наступними показниками. Загальне виробництво енергії у 2013 році склало 85,93 млн. т н.е., обсяг чистого імпорту - 31,68 млн. т н.е., при цьому викиди вуглекислого газу становили 265,05 млн. т, що в розрахунку на одну особу 5,83 т $\mathrm{CO}_{2}$ [8, с.56-57]. Це свідчить про те, що економіка України є не тільки однією 3 найбільш енергоємних у світі, вона залежна від імпортних поставок паливно-енергетичних ресурсів, а також спричиняє значний негативний вплив на довкілля. Така ситуація формує доволі нестійкий базис для подальшого економічного розвитку. Усе це створює передумови для необхідності забезпечення енергетичної безпеки, як на рівні країни, так і на рівні окремих підприємств, які споживають найбільше енергії.

Енергетичну безпеку можна розглядати в контексті безперервності енергопостачання або безперервності господарської діяльності незалежно від перебоїв живлення [9, с.1]. Це поняття $\epsilon$ достатньо широким та застосовується по відношенню до різних об'єктів управління - держави, регіонів, суб'єктів господарювання тощо.

Варто зауважити, що поняття «енергетична безпека» може розглядатися на чотирьох рівнях: мега- (рівень міжнародної енергетичної безпеки), макро- (національний), мезо(енергетична безпека регіонів) та мікрорівні (енергетична безпека окремих суб'єктів господарювання). Саме мікрорівень, тобто рівень підприємств, є базовим рівнем для забезпечення енергетичної безпеки регіону та країни

Вважаємо, що найбільш вичерпним є визначення енергетичної безпеки підприємства, запропоноване Т. Б. Надтокою та О. В. Амельницькою: «Під енергетичною безпекою підприємства варто розуміти ступінь захищеності його енергопостачання від зовнішніх $\mathrm{i}$ внутрішніх загроз в умовах нормального функціонування 3 урахуванням перспективи розвитку, а також ступінь енергозабезпечення мінімально необхідних потреб в енергії в надзвичайній ситуації» $[10$, с.18]. Якщо захищеність енергопостачання підприємства буде характеризуватися певною вразливістю до загроз, можливість підприємства виконувати свої функції може суттєво знизитися.

Тому забезпечення енергетичної безпеки підприємств зможе стати одним із найбільш суттєвих заходів $з$ переходу на шлях сталого розвитку. Основними напрямками при цьому повинні стати підвищення енергоефективності, а також використання альтернативних (відновлювальних) джерел енергії, серед перспективних напрямів розвитку яких $\epsilon$ : гідроенергетика; використання сонячної та вітрової енергії; енергії хвиль; біоенергетика; використання теплової енергії довкілля тощо. Їх застосування викликає значний інтерес, зокрема, у зв'язку з підвищенням економічності експлуатації.

Енергоефективність представляє собою підвищення коефіцієнту корисної дії при виробництві та використанні енергії. Знижуючи споживання енергії при незмінних обсягах виробництва, підприємства підвищують продуктивність використання енергії. 3 підвищенням енергоефективності покращуються якість повітря, оскільки знижується рівень викидів в атмосферу.

3 іншого боку, перехід на використання місцевих відновлювальних джерел енергії дозволить підприємствам більше контролювати систему енергопостачання та знижувати залежність від імпортного палива для генерування енергії, підвищуючи енергетичну безпеку в цьому аспекті.

Основні заходи, спрямовані на підвищення енергетичної безпеки підприємств, повинні бути пов'язані з впровадженням більш економічного транспорту, використанням новітніх технологій в освітленні (світлодіодні (LED) світильники, системи управління освітленням та ін.), збільшенням енергоефективності опалюваних будівель (модернізація тепломереж, використання енергоефективних будівельних компонентів та ін.), а також модернізацією обладнання та устаткування (мінімізація класу енергоспоживання тощо). 
Довгостроковими заходами на рівні підприємств мають стати дії з диверсифікації джерел енергії, що використовуються підприємствами для енергозабезпечення, зокрема, шляхом використання відновлювальних джерел енергії, а також диверсифікація поставок енергії; використання автономного енергозабезпечення (для виробництва теплової та електричної енергіï) і налагодження зв'язків 3 постачальниками паливно-енергетичних ресурсів для швидкого реагування на можливе припинення поставок енергії; скорочення шкідливих викидів та втрат енергії.

Вибір найкращого варіанту системи енергозабезпечення підприємства не може бути проведений без відповідної технічної підтримки виробничих процесів. Крім того, ці заходи, звичайно, не можуть бути здійснені без відповідних управлінських дій, а саме розроблення енергетичної стратегії на рівні підприємства, здійснення інвестицій в застосування енергоощадних технологій, запуску інформаційної компанії щодо економії енергії серед персоналу, проведення постійного моніторингу та оцінки ефективності дій у цій сфері.

Звісно, що забезпечення енергетичної безпеки підприємств неможливо без відповідних заходів на макрорівні. Ефективна політика держави в цьому напрямку повинна включати стимулювання розвитку нових технологій та пошуку нових енергетичних ресурсів, запровадження конкурентного та ринкового механізму для більш сталого споживання енергії, встановлення податкових пільг та надання субсидій для підприємств, що використовують енергоефективні технології тощо.

Вважаємо, що ці напрямки дій сприятимуть посиленню енергетичної безпеки як підприємств, так і держави в цілому. Знижуючи опору на імпортне викопне паливо, i, як наслідок, знижуючи тиск на бюджети, що виділяють субсидії, підвищення енергетичної безпеки підприємств сприятиме стимулюванню економічного аспекту сталого розвитку. Зрештою, це призведе до підвищення конкурентоспроможності продукції вітчизняних підприємств, а також зниження витрат споживачів. Це позитивно вплине на рівень життя найбільш вразливих верств населення та дасть можливість зробити вклад у досягнення соціальної рівності. Крім того, відповідні дії з використання альтернативних джерел енергії дозволять знизити навантаження на природні ресурси, сприятимуть покращенню якості повітря та пом'якшенню зміни клімату.

Висновки i перспективи подальших розробок. Результати проведеного дослідження свідчать про те, що між забезпеченням енергетичної безпеки підприємств та сталим розвитком існує нероздільний зв'язок. Використання енергії пов'язане 3 економічним, екологічним та соціальним аспектом сталого розвитку. Тому заходи щодо забезпечення енергетичної безпеки підприємств повинні мати пріоритетність при переході економіки на засади сталого розвитку. Вважаємо, що основними напрямками при цьому повинні стати підвищення енергоефективності та використання альтернативних джерел енергії. Заходи щодо підвищення енергетичної безпеки підприємств з метою досягнення сталого розвитку повинні бути скоординовані як на рівні самих підприємств, так і на державному рівні.

Енергетична безпека підприємства та сталий розвиток - це поняття, які складно кількісно оцінити. Тому, подальші дослідження доцільно спрямувати на вивчення питань 3 оцінки енергетичної безпеки підприємств, визначення переліку індикаторів, за якими можна дослідити рівень енергетичної безпеки та сталого розвитку.

\section{Лimepamypa}

1. Daly H. E. Beyond Growth: The Economics of Sustainable Development / Herman E. Daly. Boston: Beacon Press, 1996. - 253 p.

2. Медоуз Д. Х. Предель роста / Д. Х. Медоуз, Д. Л. Медоуз, Й. Рэндерс, В. В. Беренс. - М.: Издательство МГУ, 1991. - 207 с.

3. Melnyk L. Sustainable development on a basis of greening of production-consumption cycle / L. Melnyk, O. Melnyk, I. Burlakova // Economics for Ecology: матеріали XX Міжнар. наук. конф. (м. Суми, 6-9 травня 2014 р.). - Суми: СумДУ, 2014. - Рр. 91-93. 
4. Данилишин Б. М. Устойчивое развитие в системе природно-ресурсных ограничений / Б. М. Данилишин, Л. Б. Шостак. - К.: СОПС НАН Украины, 1999. - 367 с.

5. Баранник В. О. Енергетична безпека як складова сталого розвитку: концептуальний підхід до вибору та обтрунтування основних показників [Електронний ресурс] / B. О. Баранник. - Режим доступу до ресурсу: http://essuir.sumdu.edu.ua/bitstream/ 123456789/11071/1/4.pdf.

6. Energy for Sustainable Development [Electronic resource] // Sustainable Development Knowledge Platform. - Access: https://sustainabledevelopment.un.org/topics/energy.

7. Пудичева Г. О. Використання енергї в інтересах сталого розвитку / Г. О. Пудичева // Специфика современной науки: материаль XXV Междунар. науч.-практ. конф. (2. Горловка, 20-21 сентября 2012 г.). - Горловка: ФЛП Пантюх Ю. Ф., 2012. - С. 8-15.

8. Key World Energy Statistics, 2015 [Electronic resource] // International Energy Agency. Access: http://www.iea.org/statistics.

9. Winzer C. Conceptualizing Energy security [Electronic resource] / Christian Winzer // Cambridge Working Paper in Economics. - 2011. - № 1151. - Access: http://www.econ.cam.ac.uk/dae/repec/ cam/pdf/cwpe1151.pdf.

10. Надтока Т. Б. Енергетична безпека підприємства як інструмент забезпечення його сталого соціально-економічного розвитку / Т. Б. Надтока, О. В. Амельницька // Економіка та організація управління. - 2010. - Вип. № 2 (8). - C. 15-24.

\section{References}

1. Daly, H. E. (1996), Beyond Growth: The Economics of Sustainable, Beacon Press, Boston, $253 \mathrm{p}$.

2. Medouz, D. X., Medouz, D. L., Renders, J., Berens, V. V. (1991), Limits of growth [Predely rosta], Izdatelstvo MGU, Moskva, 207 p. (rus)

3. Melnyk, L., Melnyk, O., Burlakova, I. (2014), "Sustainable development on a basis of greening of production-consumption cycle», Economics for Ecology: Proceedings of XX International scientific conference, SumDU, Sumy, pp. 91-93.

4. Danilishin, B. M., Shostak, L. B. (1999), "Sustainable development in the system of natural resources limits» [Ustoychivoe razvitie $v$ sisteme prirodno-resursnykh ogranicheniy], SOPS NAN Ukrainy, Kiev, 367 p. (rus)

5. Barannyk, V. O. "Energy security as a component of sustainable development: conceptual approach to choosing and reasoning of the main indicators» [Enerhetychna bezpeka yak skladova staloho rozvytku: kontseptualnyi pidkhid do vyboru ta obhruntuvannia osnovnykh pokaznykiv], available at: http://essuir.sumdu.edu.ua/bitstream/123456789/11071/1/4.pdf (ukr)

6. "Energy for Sustainable Development», Sustainable Development Knowledge Platform, available at: https://sustainabledevelopment.un.org/topics/energy.

7. Pudycheva, H. (2012), "Energy using in the interests of sustainable development» [Vykorystannia enerhii $v$ interesakh staloho rozvytku], Specificity of contemporary science: Proceedings of XXV International scientific and practice conference, Horlovka, FLP Pantyukh Yu. F., pp. 8-15 (ukr)

8. Key World Energy Statistics (2015), International Energy Agency, available at: http://www.iea.org/statistics.

9. Winzer, C. (2011) "Conceptualizing Energy security, Cambridge Working Paper in Economics», No. 1151, available at: http://www.econ.cam.ac.uk/dae/repec/cam/pdf/cwpe1151.pdf.

10. Nadtoka, T. B. (2010), "Energy security of the enterprise as a tool to ensure its sustainable socio-economic development» [Enerhetychna bezpeka pidpryiemstva yak instrument zabezpechennia yoho staloho sotsialno-ekonomichnoho rozvytku], Ekonomika ta orhanizatsiia upravlinnia, Vol. 2 (8), pp. 15-24 (ukr) 